\title{
Vecsey Mariann
}

\section{A multidomén integráció lehetôségei és kihívásai}

DOI 10.17047/HADTUD.2021.31.4.27

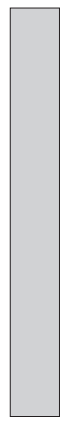

Az elmúlt évek nagyarányú technológiai fejlódése, valamint a nagyhatalmak (Amerikai Egyesült Államok, Kína, Oroszország) között egyre szúküló technológiai rés és a 2014-tól láthatóan felerősödött hibrid, aszimmetrikus vagy szürke zónás kihívások megfelelő választ kívánnak a NATO és az EU oldaláról, illetve ezen szervezetek tagállamai részéról is. 2020-ban több, olyan koncepció, illetve hivatalos kormányzati kiadvány jelent meg, amely a multidomén múködésben, a multidomén integrációban látja a megfeleló választ az új típusú kihívásokkal szemben. Jelen tanulmány célja, hogy feltárja, amit eddig tudunk a multidoménnel kapcsolatban, illetve vitaindító céllal olyan problémákat vet fel, amelyekról fontos a tovább gondolkodás egy esetleges saját, nemzeti koncepciófejlesztés kapcsán.

KULCSSZAVAK: multidomén, hibrid, reziliencia, integrált megközelítés, összkormányzati válaszok

\section{The Challenges and Opportunities of Multidomain Integration}

The rapid development in technology in recent years, the decreasing technological gap between great powers (China, Russia, United States) and the visibly increasing hybrid, asymmetric, and grey zone threats since 2014, demand sufficient answers from both NATO and the EU, as well as from their Member States. In 2020, multiple concepts and official government communications were released which claimed that the answer for these challenges lays in multi-domain operating and multi-domain integration. The aim of this issue paper is to introduce what we already developed in multi-domain, and it raises some problems which need critical thinking towards a possible national concept development.

KEYWORDS: multi-domain, hybrid, resilience, integrated approach, all-of-government answers

\footnotetext{
^ิ Nemzeti Közszolgálati Egyetem, Hadtudományi és Honvédtisztképző Kar, Hadtudományi Doktori Iskola, doktorandusz - National University of Public Service, Faculty of Military Science and Office Training, Doctoral School of Military Science;

e-mail: vecsey.mariann@uni-nke.hu; https://orcid.org/0000-0001-7134-3666
} 


\section{Bevezetô}

A Krím-félsziget orosz annektálását követően megnövekedett azon konferenciák, tudományos munkák száma, amelyek a hibrid fenyegetésekkel, az aszimmetrikus kihívásokkal és a szürkezónás konfliktusokkal foglalkoztak. Ezek szinte mindegyike, az események leírásán, elemzésén kívül, olyan válaszokat is keresett az új típusú kihívásokara, melyek hatékonyak lehetnek ezekben a nem-konvencionális helyzetekben. Az új típusú kihívások mellett egyre szembe ötlóbb az újonnan megjelenó forradalmi technológiák (mesterséges intelligencia, big data, kvantum technológia, autonóm rendszerek, biotechnológia) fejlődése, valamint azok alkalmazásának lehetôségei. Erre a komplex problémára komplex választ kell adnia a Nyugatnak, egyes országoknak és szövetségi rendszereknek egyaránt. A megindult koncepciófejlesztések alapján a többdimenziós (multidomén/multitér) múvelet (Multi-Domain Operation - MDO) és a multidomén integráció lehet az a válasz, amely elég komplex és szerteágazó ahhoz, hogy a fentebb felsorolt minden kihívásra egyszerre adhasson hatékonyan választ. A koncepció azonban még kiforratlan, jelenleg is zajlik a kidolgozása mind nemzeti, mind szövetségesi szinten. A NATO az MCDC ${ }^{1}$ projekten belül egy munkacsoportot hozott létre a közös álláspont kialakítására és a NATO Szövetséges Transzformációs Parancsnokság (ACT) vezetésével megkezdete a „Kezdeti Multidomén Koncepció” (initial Multi-Domain Concept) kidolgozását. Pontosan ez a kezdeti fázis az, amely lehetóvé teszi azt, hogy vitaindító, gondolatébresztő munkák szülessenek a multidomén koncepció kialakításának kapcsán. Jelen tanulmány célja az eddigi konferenciákon elhangzott információk összegzése, a már meglévő dokumentumok és koncepciók ismertetése. A multidoménhez kapcsolódó terminológia kialakítása is folyamatban van, ezért az egyszerúség és érthetôség követelményeinek is eleget téve, egy terminológia kerül következetesen alkalmazásra, követve a témában megjelent, Mezó András által jegyzett, magyar nyelvú tanulmányt. ${ }^{2}$

A tanulmány elsố alfejezetében kerül sor a multidoménhez kapcsolódó már meglévő fogalmak tisztázására, az esetleges kapcsolódó viták ismertetésére. Ilyen a multidomén egyik feltételezett kiindulópontja, a társadalmi reziliencia, melynek hiányában a társadalom sérülékenysége magasabb az új típusú fenyegetésekkel szemben. Az új típusú fenyegetéseket, kiemelten a hibrid fenyegetéseket szintén bemutatja a tanulmány, hiszen a terminológia alkalmazása e tekintetben sem egységes. A hibrid fenyegetések bemutatásához Kiss Álmos Péter, ${ }^{3}$ valamint Somodi Zoltán - Kiss Álmos Péter ${ }^{4}$ összefoglaló munkáit használtam fel. Emellett, a komplex problémákra adott válaszok az EU és ENSZ által már feltalált módszere az integrált

1 Az MCDC (Multinational Capability Development Campaign - Többnemzeti Képességfejlesztési Kampány) az Egyesült Államok Joint Staff J7 kezdeményezése. Kutató hálózat, amelyben 24 nemzet fegyveres erói, kutatóintézetei és egyéb intézményei, valamint a NATO ACT és a European Defence Agency (EDA) vesznek részt. Célja azonosítani a többnemzeti múveletek képességbeli és egyéb hiányosságait, és ezekre közös megoldást találni a koncepció-, doktrína- és más képességfejlesztési területeken.

2 Mező 2020; Mezó 2021, 3-20.

3 Kiss 2019.

4 Somodi, Kiss 2019. 
megközelítés, melyet szintén bemutatok jelen tanulmányban. Ez az elem a multidomén múködés egyik sarokköve, mely hatékonyan mutatja be a komplex problémákra adott válaszok összetettségét. Végül a multidomén kialakulóban lévő fogalmát is bemutatom, mely, ha jelen állapotában nem is végleges, de jó kiindulási alapként szolgálhat. A második alfejezet a multidomén eddigi megjelenését dolgozom fel a különbözó szövetséges nemzetek szakirodalmában. Ezen már kiadott és elérhetố koncepciók összehasonlítását végzem el, melyen keresztül láthatóvá válik annak még kiforratlan jellege és a vele kapcsolatos kérdések. A tanulmány utolsó fejezete összegzés helyett egy kitekintést, kérdésfeltevést és alapvetően a multidoménnel szemben felmerülő kihívásokat tárgyalja, mely szintén további gondolatébresztóként funkcionálhat a koncepció fejlesztését illetôen.

\section{Módszertan és fogalomtisztázás}

A multidoménnel kapcsolatos releváns nemzeti és szövetségesi elsődleges források vizsgálatát a dokumentumelemzés és tartalomelemzés módszerével dolgoztam fel a tanulmányban. A módszerek kiválasztására fóként a téma újdonsága, a vele kapcsolatos, még folyamatban lévő terminológiai és értelmezési viták miatt volt szükség. Ezen kutatási módszerek alkalmazásával a multidomén jelenlegi kidolgozottsága nagyobb pontossággal mutatható be az olvasónak.

Az elsó és egyben legfontosabb fogalom, amelyet ismerni kell a multidoménhez az a hibrid hadviselés, melyre válaszként született meg az MDO. A hibrid fenyegetések ismerete nélkül nem lehet azokra hatékony válaszokat adni. A szakirodalom átfogó tanulmányozása után Kiss és Somodi összefoglaló tanulmányban négyféle megközelítési módot mutat be a hibrid hadviselés megítélésével kapcsolatban.

1. Teljesen újfajta hadviselés, új stratégiai szemlélettel, melyre speciális és modern válaszokat kell adni.

2. A módszer nem új, egyes elemei már korábbi konfliktusokban is jelen voltak, de tartalmaz valamilyen speciális új elemet, például a kiber domént.

3. Nincs benne újdonság, a megalkotókat jellemzi, nem pedig azt a tevékenységet, amit le akarnak írni vele. A hidegháború elótti módszerek alkalmazásának váratlan visszatérését írják le vele tulajdonképpen.

4. Az orosz stratégiai gondolkodás szerint pedig a hibrid hadviselés a nyugati hatalmak Oroszország elleni stratégiája.

A NATO 2014-es értelmezésében, a hibrid fenyegetés széles körü nyillt és fedett katonai, félkatonai és nem katonai eszközök és eljárások alkalmazása egy szorosan integrált müveleti terv mentén. ${ }^{6}$ Késóbb a szervezet úgy írta le a hibrid hadviselést, mint olyan fenyegetés, amely hagyományos, irreguláris és aszimmetrikus tevékenységeket ötvöz térben és idóben.

5 Somodi - Kiss 2019, 22-26.

6 Kiss 2019, 18.

7 A NATO meghatározás angolul. Hybrid threat: A type of threat that combines conventional, irregular and asymmetric activities in time and space. (NATO Agreed) NATO Standardization Office, NATO Term https://nso.nato.int/natoterm/Web.mvc (Letöltés idôpontja: 2021. 08. 30.)

MH Szabványosítási és Doktrinális Tanács, Terminológiai Harmonizációs Testület, 2019. 
Egy ilyen összetett és vitákkal övezett kihívásra nem lehet egyszerú választ adni, és maga a válasz is bizonyosfokú összetettséget kell, hogy felmutasson. Az Egyesült Nemzetek Szervezete (ENSZ) 2006-ban megalkotta a válságkezeléssel kapcsolatos integrált megközelítését, amely elsősorban egy szervezeti szintú, de teljes, minden területen megvalósuló együttmúködést irányzott elő. ${ }^{8}$ Az Európai Unió ezt a koncepciót vette át, amikor 2016-ban felismerte, hogy komplex kihívásokra integrált választ kell adni, hogy siker koronázhasson egy-egy beavatkozást. Az EU olvasata szerint az integrált megközelítés többdimenziós, tehát az EU rendelkezésére álló valamennyi szakpolitikai eszközt felhasználja, többfázisú, tehát a konfliktusok minden szakaszában tevékeny, többoldalú (multilaterális), tehát szükséges a regionális és nemzetközi partnerségekkel való együttmúködés és többszintü, tehát különböző kormányzati szinteken is fellép. ${ }^{9}$ Ennek megfelelóen a brit koncepció megalkotásakor is különös figyelmet szenteltek a négy "több” meglétének, mely a következóképpen fordítható le:

A multidomén koncepció

1. többdimenziós: lefedi a multidomént, az öt domén (ür, kiber, szárazföldi, légi, tengeri) szoros együttmúködését irányozza elő;

2. többszintú: a nemzeti (lokális), regionális, valamint globális értelmezési tartományban is átfogó gondolkodást tart célravezetônek nemcsak a haderó, valamint a szövetségi rendszerek bevonásával, hanem más, társadalmi, tudományos területekról egyaránt;

3. többoldalú: több szereplő bevonásával igyekszik bemutatni nemzeti ellenálló-képességeit globálisan;

4. többfázisú: talán ez a legkevésbé beilleszthetố az Európai Unió Globális Stratégiájába, amelynek lényege az, hogy egy konfliktus során az EU bármely pillanatban be tudjon avatkozni. A brit koncepció középpontjában „lakosság centrikus” gondolkodás áll az „ellenség centrikus” gondolkodással szemben, azaz egy olyan integrált cselekvés gondolata, amely megköveteli a parancsnokoktól, hogy az ellenség megsemmisítésén helyett inkább azokat a hatásokat mérlegeljék, amelyeket a konfliktus szereplóire (különösen a helyi lakosságra) kell gyakorolni a múvelet céljainak elérése érdekében. Rövidebben: a múvelet kognitív dimenziójában elért hatások elsóbbséget élveznek a virtuális és a fizikai hatásokkal szemben. ${ }^{10}$

Ennek megfelelóen a multidomén múködés nem egy önmagában értelmezhetố és elôzmények nélküli koncepció. A koncepció más folyamatokra való épülésével és kapcsolatával biztosítható annak szilárdsága és alkalmazhatósága.

8 de Coning 2008, $10 .$.

9 Közös jövốkép, közös fellépés: Erôsebb Európa Globális stratégia az Európai Unió kül- és biztonságpolitikájára vonatkozóan 2016, 23.

10 UK Ministry of Defence:Introducing the Integrated Operating Concept. 2020, 12. 


\section{Ellenállóképesség}

A teljesség igénye nélkül, de az elmúlt, multidoménnel kapcsolatok konferenciák leggyakoribb szereplóje a reziliencia, azaz az ellenállóképesség volt. E nélkül nem lehet sikeres multidomén múködést elérni. A reziliencia azért nagyon fontos kiinduló elem, mert a társadalom egészét érinti ugyan, de az egyén, mint annak alapvetó alkotóeleme is fontos. Itt azonban ismét meg kell jegyezni, hogy a reziliencia is egy olyan kifejezés, melynek általánosan elfogadott magyar megfelelóje még nincs, ezért a multidomén probléma többszörösen is összetett. A reziliencia kifejezés leginkább és jelen helyzetben is alkalmazott magyar nyelvú megfelelóje a rugalmas ellenállási képesség. A kifejezéshez tartozó definíciók képlékenyek, de mindegyik olyan módon tekint a fogalomra, mint egy egyén, szervezet vagy ökoszisztéma eróteljes, megújuló, külsô, sokkszerú behatásokra való reaktív képesség, az azokhoz való sikeres adaptáció, illetve a kiindulási állapothoz való gyors visszatérés a sokk átélése után. ${ }^{11}$ A definícióból is kikövetkeztethetố, hogy ez a képesség azért fontos multidomén környezetben, mert a hibrid hadviselés gyakran idéz elố sokkhatásokat a társadalom részét vagy egészét érintôen, váratlan, illetve ismétlódô módon is. ${ }^{12}$

\section{Brit multidomén integráció}

A multidomén múködéssel, integrációval kapcsolatban a legátfogóbb módon az Egyesült Királyság foglalkozik, ezért ezt a koncepciót mutatom be. Az integrált megközelítés az EU Globális Stratégiájának vívmánya, melyet az Egyesült Királyság sikerrel adaptált a multidomén múködés leírásához, amely az eddig legrészletesebben megalkotott koncepció. A jelenlegi brit gondolkodás szerint az összkormányzati együttmúködés alkotja a multidomén múködés/integráció egyik pillérét, mely kiegészül az öt múveleti doménben (legalább párhuzamosan kettó, de inkább valamennyi doménben), stratégiai, múveleti és harcászati szinten is koordináltan végzett katonai tevékenységekkel. A brit felfogás szerint az öt domén: a szárazföldi, a tenger, a levegố, az ưr, valamint a kibertér és elektromágneses domének. Az öt domén közül kiemelkedô az ứr domén, valamint a kibertér és elektromágneses domén, mert jellegüknél fogva összekötik a másik hármat is. Az úr domén fontos eleme a navigációnak, kommunikációnak, valamint az aktuális helyzet múholdas térképek alapján való vizualizációjának. Az ứr domén azonban szintén erôsen függ a kiber és elektromágneses doméntól, hiszen a parancsnok e domén révén szerez tudomást a kialakult légi, tengeri, szárazföldi és úrhelyzetról, illetve az e doménben kifejtett tevékenységével tudja irányítani a múveleteket.

11 Székely 2015, 9.

12 A NATO-nak van ugyan információ technológiai fogalmi meghatározása a rezilienciára, de ez ebben az esetben csak módosításokkal lenne elfogadható. A NATO meghatározás angolul: „The ability of a functional unit to continue to perform a required function in the presence of faults or errors." (NATO Adopted) Magyarul: „Ellenállóképeség (reziliencia): Egy funkcionális egység képessége, hogy betöltse megszabott feladatát hiba vagy tévedés esetén is." NATO Standardization Office, NATO Term https://nso.nato.int/natoterm/Web.mvc (Letöltés időpontja: 2021. 12. 13.) 
A több doménben való múködés mellett az azokat átölelő három dimenzióban (kognitív, virtuális és fizikai) kifejtett hatásokkal is számolni kell (lásd 1. ábra). A brit elképzelés asszertívabb magatartás kialakítását javasolja, illetve a fontossági sorrend újra gondolását a rugalmas ellenállóképesség és a készenlét fokozásának irányába. A koncepció hozzáteszi, hogy az ipari korból az információ korába lépve erôsen javasolt az információs fölény megszerzésére törekedni. Szükséges az újonnan megjelenó forradalmi technológiák haderóbe, a hibrid kihívásokra adott válaszokba való beépítése, mivel a célok elérése immár háborús küszöb alatti múveletekkel is sikeresen elérhetố, mint azt a Krím-félsziget 2014-es annexiója is jól példázta. ${ }^{13}$

A multidomén pontos definíciójának hiánya teret enged a meglévő pontok kiegészítésére és további gondolkodásra a koncepciót illetóen.

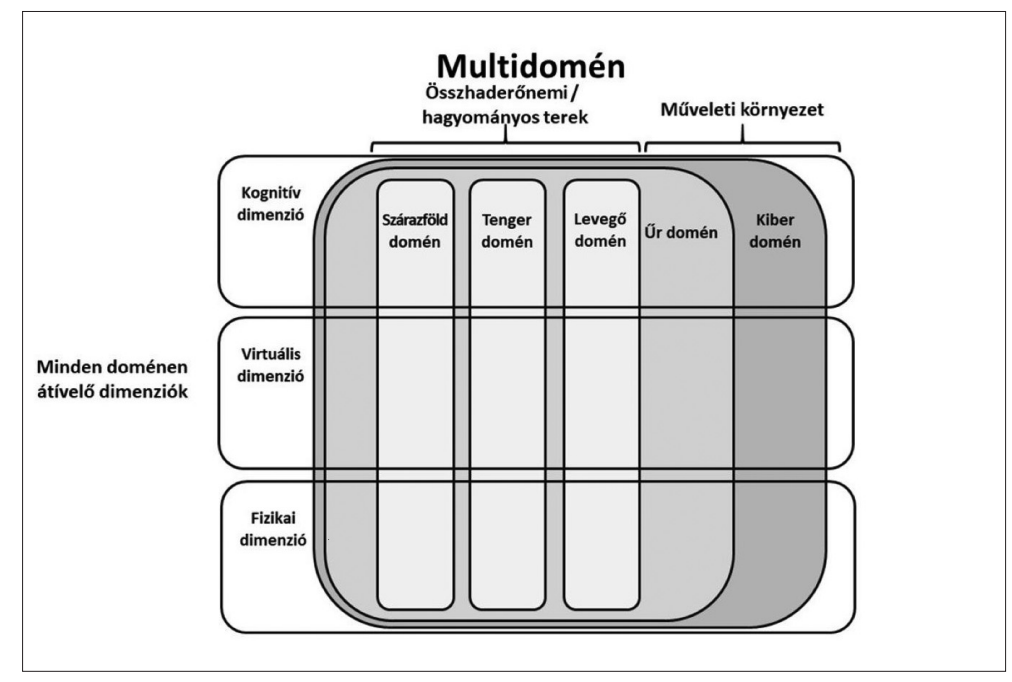

1. ábra.

A mûveleti környezet benne az öt domén, ahol múveletek zajlanak és a három dimenzió, ahol azok hatása megjelenik

(Szerkesztette: a szerzó)

Az elmúlt időszakban folyamatosan megjelent brit anyagok tanulsága szerint az Egyesült Királyságban a multidomén múködés/integráció egy felülról lefelé (top-down process) irányuló folyamat. A 2021-ben megjelent, az ország kormánya által jegyzett Global Britain 2040 címú stratégiai kitekintó dokumentum is ezt támasztja alá, melyben megjelenik a multidomén integráció összkormányzati szinten is. ${ }^{14}$ Igy feltehetô, hogy az Egyesült Királyságban azért lehet egységesebb a kép az új fogalmat illetôen, mert kormányzati akarat is párosul a szükségszerú és időszerú koncepcióváltással a haderố alkalmazásának tekintetében. A brit koncepció fóbb ismérvei

13 UK Ministry of Defence: Introducing the Integrated Operating Concept. 2020, 5-10.

14 Az Egyesült Királyság Kormánya 2021, 19. 
az összkormányzati jelleg mellett, hogy 5 domént vesznek számításba, a szárazföldit, légit, tengerit, úrt és kibert, mely utóbbiba sok államtól eltérô módon az elektromágneses teret is beleértik. ${ }^{15}$

\section{Nemzetközi multidomén gondolkodás}

Az Amerikai Egyesült Államok nem ilyen egységes az eddig megjelent dokumentumok alapján. Egy 2003-ban megjelent RAND elemzés megmutatja, hogy az amerikai - egyáltalán nem kormányzati - elképzelés szerint a multidomén már közel 20 évvel ezelótt is mindössze a három összhaderőnemi múveleti tér, valamint az úr képességek bevonását, illetve a különleges múveleti erók más haderónemekkel való magasabb szintú együttmúködését jelentette. ${ }^{16} \mathrm{Ez}$ a gondolkodás az elmúlt idôszakban sem ment át nagyobb változáson a NATO vezetố nemzeténél. Egységes amerikai stratégia dokumentum még nem látott napvilágot a multidomén témakörben, vagy az nyîlt forrásból nem hozzáférhetô. Ami világos a haderônemek elképzeléseit illetốen, az az, hogy mind az öt haderónem foglalkozik vele, egyfajta kiterjesztett összhaderónemi múveletként tekint rá, de az alkalmazott szakterminológia haderónemenként eltéró. A szárazföld multidoménként, illetve egymást átfedő doménként (multi-domain és cross-domain) írja le, ${ }^{17}$ míg a légieró összdoménként (joint all-domain) hivatkozik rá. ${ }^{18}$

Spanyolország haderó szinten kezdett el a multidomén jelenséggel foglalkozni, méghozzá egy vitaindító dokumentummal, melyben a terminológia, valamint a definíció nemzeti kialakítása az elsốdleges cél. A spanyol dokumentum továbbá felveti egy esetleges hatodik domén lehetôségét, amely a kognitív domén lehet. ${ }^{19}$ Ez félreértése az eddigi termionlógiának, hiszen a kognitív dimenzió az, amelyben a hatások keletkeznek a doménekben kifejtett tevékenység nyomán. ${ }^{20}$

A multidomén múködést/ integrációt érintóen a holland gondolkodás legprominensebben a holland védelmi minisztérium 2020-ban kiadott Defence Vision 2035 címú dokumentumában jelent meg. Itt ismét elôtúnik, hogy a multidomén múködés minden nemzetnek mást és mást jelent. A holland stratégiai dokumentum a kibertérre, az információs múveletekre és a technológia-orientált fejlesztésekre helyezi a hangsúlyt. Mindezt azért, mert e szegmensek fontossága egyre növekszik, és ebben a környezetben jelennek meg a hibrid fenyegetések is. Ez a fizikai térból való áttolódás már nem csak katonai válaszokat igényel, hanem bóvebb civil-katonai együttmúködést a fenyegetésekre való válaszadás során. Elótérbe kerül az összkormányzati megközelítés, de a hálózatalapú múveletek alkalmazásának lehetősége is. ${ }^{21} \mathrm{~A}$ dokumentumot a védelmi minisztérium jegyzi, így a holland elképzelés feltehetôen egy alulról felfelé irányuló kezdeményezés, hiszen nincsen olyan összkormányzati támogatás

15 UK Ministry of Defence: Introducing the Integrated Operating Concept 2020, 5.

16 Gompert 2003, 11.

17 TRADOC 2018, 19.

18 Air Education and Training Command 2020.

19 Ministry of Defence, Defence Staff, Spain 2020, 1-2.

20 Mező 2020, 72.

21 Ministry of Defence, the Netherlands 2020. 
mögötte, mint az Egyesült Királyság Kormánya által jegyzett dokumentum a brit koncepció mögött.

Franciaország, szintén a haderó szintjén adta ki 2020 decemberében a multidomén múködéssel/integrációval is foglalkozó Armed Forces Employment Concept-et. Ez alulról fölfelé irányuló kezdeményezést jelent, hiszen itt sincs kormányzati dokumentum a haderő koncepciója mögött. A dokumentumban szembetúnó az Európai Unió nyelvezetének kiterjedt alkalmazása az olyan fogalmak tekintetében, mint az átfogó vagy az integrált megközelítés. Az új típusú kihívások miatt esedékes haderóreform legfontosabb hívószava is az integráció. A francia dokumentumban az integráció koncepciója úgy jelenik meg, mint a helyzetek legszélesebb körú/legalaposabb ismeretére való törekvés, minden szerepló aktív közremúködése, a hatások összességében a szinergiák elérésére való törekvés, amely térben és idóben koncentráltan vagy szétszórva jelenik meg a teljes spektrumban, legyen az fizikai vagy virtuális, egy cél elérése érdekében. Emellett az integráció az összes domént magába foglaló múveleteket takar, melyekhez szükséges a civil-katonai együttmúködés. Ez utóbbi nagy valószínúséggel az összkormányzati együttmúködést jelenti, kiegészülve nemzetközi szervezetekkel és nem kormányzati szervezetekkel való együttmúködéssel. A francia dokumentumban többszintú az integrációval kapcsolatos kritikus igény: harcászati, hadmúveleti és stratégiai szinteken is elvárt az együttmúködés elmélyítése. Erre a domének nagy interdependenciája miatt van szükség, és helyzetról-helyzetre, ad hoc jelleggel egyedi elbírálás alá esik, hogy milyen választ ad az ország. ${ }^{22}$

\section{Kihívások és kérdések}

A multidomén múveletek/integráció egy kialakulóban lévô koncepció, melynek elsődleges meghatározása több kihívással szembesíti az elméleti szakembereket. Az alapvetố fogalmak tekintetében is igen nagy a bizonytalanság, mint például a hibrid hadviselés is általánosan elfogadott definíció nélkül maradt, miközben a hibrid fenyegetést definiálták. Így érdemes feltenni a kérdést, hogy valóban szükség van-e egy konkrét, határok közé szorító fogalom kialakítására, amely szükségtelenül leszúkíti a komplex, interdiszciplináris multidomén múködés értelmezését?

A következő izgalmas felvetés a Warfare Development Talks (WDT) ${ }^{23}$ ülésén fogalmazódott meg a résztvevókben, méghozzá mintegy arra a brit felvetésre reagálva, amely szerint a nyugati múveletek túlságosan transzparensek. A multidomén múvelet, múködés és integráció felfogható-e a demokráciák hibrid hadviseléseként? Hiszen ugyanarról a típusú hadviselésról, az ilyen fenyegetésekre válaszul kialakulóban lévő reagálásról beszélünk. Egyértelmú, hogy egy demokráciában nem úgy múködik a stratégiák, múveletek tervezése, mint egy diktatúrában, ahol a jobbára egyszemélyi vezetés vagy vezetói csoport gyorsan hoz döntéseket a beavatkozások minden területét illetốn. Most gyakorlatilag a demokratikus stratégiai döntéshozatal

22 Ministry of Defence, France 2020, 25-30.

23 Warfare Development Talks on Multi-Domain Operations Approach 2021. június 16-17. ACT/SPP/WDF/TT- 4160/SER:NU0541. 
felgyorsítását túzték napirendre, hogy képes legyen megfelelni az autokrata vezetésú államok gyors, egyszemélyi döntéseinek.

A WDT üléshez kapcsolódó gyakorlat helyzetbeállítása nem sokban különbözött a már eddig is megszokott gyakorlatoktól. Tulajdonképpen egy konvencionális katonai lépést követeló helyzetképet alakítottak ki. Sokkal hatékonyabban készülhetünk a jövő konfliktusaira, ha alapvetóen egy hibrid vagy nehezen felismerhető, lassan eszkalálódó konfliktust szimuláló gyakorlatot dolgozunk ki. Ez jobban hasonlít azokra az eljárási formákra, amelyeket az eddigiekben is tapasztalhattunk a hibrid konfliktusok során. A meglévő tapasztalatokat nem csak feldolgozni, hanem integrálni is kell a katonai kiképzésbe, felkészítésbe. A kihívás az, hogy olyan realisztikus gyakorlatokat is fel tudjunk építeni a továbbiakban, amelyek valóban megkövetelik a multidomén reakciót, és a valóságban is alkalmazott eljárásokra támaszkodik. Ilyen lehet egy dezinformációs kampány indítása gazdasági térnyerés céljából, kibertámadás, olyan módon, amely elsốdleges gyanút nem kelt, például túlterheléses támadás, tanácsadók elhelyezése a célország különböző szektoraiban, akár katonai magánvállalatok megjelentetése a leírásban. Nem szabad azonban arra törekedni, hogy az eljárásrendek ilyetén felsorolása már egy kifejezett országra terelje a gondolatokat, hanem vegyesen és variálva kell kialakítani a gyakorlatok során a helyzetképet. Ehhez a várható szemben álló felek harceljárásainak átfogó ismerete szükséges, például „red team” ${ }^{24}$ létrehozásával a hadmúveleti részlege(ke)n.

A multidomén múködés és integráció a fentebb ismertetett nemzeti példákon keresztül láthatóan is különbözố szintekról indulhat. A brit, amely az egyetlen felülról jövő kezdeményezést mutató koncepciókialakítás, lehet az előre vezető példa. A WDT ülésén szintén elhangzott, hogy a multidomén által feltehetően megkövetelt összkormányzati jelleg azt sejteti, hogy a koncepcióváltást egy felülról jövő kezdeményezés formájában lehet sikerrel bevezetni. Erre azért van szükség, mert már nem csak a haderő vesz részt a fenyegetésekre való válaszadásban, hanem elengedhetetlen valamennyi kormányzati terület együttmúködése a sikeres fellépéshez. Joggal merül fel a kérdés, hogy van-e legitimitása annak, hogy a Magyar Honvédség önállóan alkosson meg egy koncepciót, minden más szereplótól függetlenül?

Ennél sokkal alapvetóbb kérdést vet fel az az elmélet, amelyet Sven Biscop is bemutatott 2019-ben kiadott könyvében, miszerint a hibrid hadviselés nem hibrid hadviselés, hanem konvencionális, hiszen a szemben álló felek eddig is és ezután is minden rendelkezésükre álló eszközzel igyekeznek a fölény megszerzésére. ${ }^{25} \mathrm{Ez}$ alapjaiban változtatná meg a multidoménhez való hozzáállást.

Azonban ha azt vizsgáljuk, hogy melyek a multidomén múködéshez szükséges alapvetố feltételek, akkor szintén olyan fogalmakba ütközünk, melyekkel e tanulmány elején is adódtak terminológiai nehézségek, de túl a definíciók hiányán az sem

24 A Red Team feladata eredetileg az volt, hogy bármely stratégiai elképzelés, terv, koncepció gyenge pontjait megtalálja, megkérdójelezze a feltételezéseket, rámutasson a logikai hibákra, kiszélesítse az információgyújtés területeit, különbözó opciókat és alternatívákat azonosítson, valamint stressz-tesztelje azokat. UK Ministry of Defence 2021. Red Teaming Handbook.

https://assets.publishing.service.gov.uk/government/uploads/system/uploads/attachment _data/file/1027158/20210625-Red_Teaming_Handbook.pdf (Letöltés ideje: 2021. 08. 10.) 
világos, hogyan tudnák a NATO-erók érdemben befolyásolni az ellenállóképesség kialakítását összkormányzati közremúködés nélkül. A reziliencia például és ezen belül a társadalmi reziliencia megléte egy fontos alapkövetelménye a multidomén múködésnek. Éppen ezért, a koncepció kialakítása meglehet, hogy egy gyorsabb folyamat lesz, de a "múködési készenlét” elérése évek munkája és nem csak a haderót érintó programok eredménye lehet.

Egy ilyen, haderôt érintố program a küldetésorientált vezetési forma, MDO vezetésének a kialakítása. Ezzel már elkezdett ugyan foglalkozni a Magyar Honvédség, de kivitelezése évekbe telhet. ${ }^{26}$ A NATO MCDC projektek között szintén megjelenó vezetési modellnek a jelentôsége abban áll, hogy a multidomén múködés alapvetô vezetési formájává válhat. Erre fóként azért van szükség, mert a döntési modell, amelyet ez a vezetési forma alkalmaz, különösen alkalmas a napjainkban megjelenó komplex problémáka való válaszadásra. A küldetésorientált vezetés ehhez a Cynefin döntési modellt alkalmazza, amely leírja az egyszerú, bonyolult, kaotikus és komplex problémákat. Ezek közül manapság a komplex vagy gonosz/komisz problémák (wicked problem) dominálnak. A komplex problémák megoldását nem lehet egy elốre meghatározott algoritmus alapján megoldani, hiszen mindegyik más és más, egyedi jegyekkel, melyek hasonlóan egyedi megoldásokat követelnek. ${ }^{27}$

Emiatt a nagyfokú bizonytalansági tényezố miatt is megkérdójelezhetố annak hasznossága, hogy a multidomént egy tiszta határvonalakat felrajzoló definícióval skatulyázzuk be, a válaszadás hatékonyságát is veszélyeztetve akár. Hiszen napjaink új típusú kihívásai a legtöbbször komplex problémákként jelentkeznek, melyekre hasonlóan összetett válaszokat kell adnunk.

\section{Befejezés}

A tanulmány közel sem fedi a multidomén integráció minden aspektusát, de a cél nem a probléma teljeskörú bemutatása volt, hanem a formálódó koncepció körül már kialakult, szubjektív megítélés alapján legérdekesebb, legkomplexebb kérdések ismertetése. Ilyenek a multidomén koncepcióhoz szorosan kötődó fogalmak körüli tisztázatlan kérdések, mint például a hibrid fenyegetés. Ilyen a koncepció egyik alkotóelemét képező integrált megközelítés, amelyet már az ENSZ és az EU is alkalmazott fóként válságkezelést érintően, missziókkal kapcsolatban. Emellett bemutattam azon NATO-tagállamok multidoménnel kapcsolatos elképzeléseit, amelyek nyílt forrásból elérhetố módon közölték az új koncepciót érintô, még akár kialakulóban lévố gondolataikat. Így amerikai, brit, francia, holland és spanyol, fóként minisztériumok vagy a nemzeti haderó által jegyzett dokumentumokat dolgoztam fel. Ezek nagyon is változatos kidolgozottsága néhol szembeötló különbözôséggel is párosul. Emellett

26 Magyar Honvédség Transzformációs Parancsnokság, Honvéd Tudományos Kutatóhely: Küldetésorientált vezetés (elmélet és gyakorlat) zártkörú oline workshop 2021. március 24.

https:/intranet/Lists/mhkiphirdetmenyek/AllItems.aspx (A konferencia videó-anyaga az STN rendszerben az alábbi linken érhető el: https://tudastar.mil.hu/ourpipe/?watch=15\&playlist=f7d9cd852fd94f001e3bdf14058ba4f7) (Letöltés ideje: 2021. 12. 13.) MCDC Project 2020, 13-15. 
olyan kérdések is felmerülnek a multidomén múködéssel kapcsolatban, melyek provokatívak, de céljuk minden esetben a gondolkodási folyamat elindítása a témában. Ezen kérdések a következóek:

1. A multidomén múvelet, múködés és integráció felfogható-e a demokráciák hibrid hadviseléseként?

2. Mivel valamennyi kormányzati terület együttmúködése elengedhetetlen a sikeres fellépéshez, van-e legitimitása annak, hogy a Magyar Honvédség önállóan alkosson meg egy koncepciót, minden más szereplótól függetlenül?

3. Hogyan akarjuk a tapasztalatokat a gyakorlatba is átültetni, ha nem tudunk realisztikus gyakorlatokat felépíteni, amelyek valóban multidomén választ követelnek?

Ennek megfelelően célom egy olyan szakmai diskurzus megindítása, amely elórébb viszi a multidomén integráció nemzeti koncepciójának kialakítását, elősegíti a konstruktív terminológiai vitát. Remélem ezen írás komplexitása miatt felkelti a szúkebb katonai-szakmai közönség figyelmén túl a magyar katonai stratégiai és politikai élet képviselóinek figyelmét is. Ennek megvalósulásával olyan párbeszéd alakulhat ki, akár e folyóirat hasábjain is, amely egy valóban multidomén koncepció kidolgozását eredményezheti magyar vonatkozásban.

\section{FELHASZNÁLT IRODALOM}

Air Education and Training Command: Air Force releases Joint All-Domain Operations doctrine. https://www.aetc.af.mil/News/Article-Display/Article/2212411/air-force-releases-joint -all-domain-operations-doctrine/

Az Egyesült Királyság Kormánya: Global Britain in a competitive age The Integrated Review of Security, Defence, Development and Foreign Policy. HM Government CP 403 Presented to Parliament by the Prime Minister by Command of Her Majesty. March 2021.

https://assets.publishing.service.gov.uk/government/uploads/system/uploads/attachment _data/file/975077/Global_Britain_in_a_Competitive_Age-_the_Integrated_Review_of_Security _-Defence_Development_and_Foreign_Policy.pdf

Biscop, Sven 2019. European Strategy in the 21st Century. Oxon: Routledge. https://doi.org/10.4324/9780429427442

de Coning, Cedric: The United Nations and the Comprehensive Approach. https://www.diis.dk/files/media/publications/import_efter1114/report-2008-14_the_united nnations_and_the_comprehensive_approach.pdf

Gompert, David C. 2003. Preparing Military Forces for Integrated Operations in the Face of Uncertainty. RAND, Issue Paper. https://www.rand.org/content/dam/rand/pubs/issue_papers/2005/IP250.pdf

Hegedús Ernő, Hennel Sándor 2020. Többdimenziós (multidomain) hadmúveletek. Hadtudomány 30 (2): 3-27. https://doi.org/10.17047/HADTUD.2020.30.2.3

Kiss Álmos Péter 2019. A hibrid hadviselés természetrajza. Honvédségi Szemle 147 (4): 17-37. https://kiadvany.magyarhonvedseg.hu/index.php/honvszemle/article/view/237/229

Közös jövốkép, közös fellépés: Erôsebb Európa Globális stratégia az Európai Unió kül- és biztonságpolitikájára vonatkozóan. https://eeas.europa.eu/archives/docs/top_stories/pdf/eugs_hu_.pdf

Magyar Honvédség Transzformációs Parancsnokság, Honvéd Tudományos Kutatóhely: Küldetésorientált vezetés (elmélet és gyakorlat) zártkörú oline workshop 2021. március 24.

https://intranet/Lists/mhkiphirdetmenyek/Allitems.aspx (A konferencia videó-anyaga az STN rendszerben az alábbi linken érhetô el:

https://tudastar.mil.hu/ourpipe/?watch=15\&playlist=f7d9cd852fd94f001e3bdf14058ba4f7) 
MCDC Project 2020. Future Leadership. https://assets.publishing.service.gov.uk/government/uploads /system/uploads/attachment_data/file/946243/20201210-MCDC_Future_Leadership-web.pdf

Mező András 2020. "Report on JAPCC Multi-Domain Conference." Hungarian Defence Review 148 Special Issue (1): 69-78. https://kiadvany.magyarhonvedseg.hu/index.php/honvszemle/issue/view/11/13 https://doi.org/10.35926/HDR.2020.1.6

Mező András 2021. Multidomén múveletek vezetése és irányítása. Hadtudomány 31 (1): 3-20. https://doi.org/10.17047/HADTUD.2021.31.1.3

MH Szabványosítási és Doktrinális Tanács, Terminológiai Harmonizációs Testület, 57-15/2019. Feljegyzés. 2019. augusztus 28 .

Ministry of Defence, Defence Staff, Spain 2020. Concept Note "Multi-Domain Operations". https://www.defensa.gob.es/ceseden/Galerias/ccdc/documentos/Concept_Note_on _Multi-domain_Operations.pdf

Ministry of Defence, France 2020. Armed Forces Employment Concept. https://betterplace.info/files/706599-complement.pdf

Ministry of Defence, the Netherlands 2020. Defence Vision 2035 Fighting for a safer future. https://www.paysbasetvous.nl/binaries/fr-netherlandsandyou/documents/publications /2020/11/04/vision-defense-2035/Defence+Vision + 2035.pdf

NATO Standardization Office, NATO Term https://nso.nato.int/natoterm/Web.mvc

Somodi Zoltán, Kiss Álmos Péter 2019. A hibrid hadviselés fogalmának értelmezése a nemzetközi szakirodalomban. Honvédségi Szemle 147 (6): 22-28.

http://real.mtak.hu/105176/1/Somodi-ZoltC3A1n-C591rnagy-E28093-Kiss-C381lmos-PC3A9ter _A-hibrid-hadviselC3A9s-fogalmC3A1nak-C3A9rtelmezC3A9se -a-nemzetkC3B6zi-szakirodalomban.pdf

Székely Iván 2015. Reziliencia: a rendszerelmélettól a társadalomtudományokig. Replika (5): 7-23. http://www.replika.hu/system/files/archivum/94_01_szekely.pdf

TRADOC 2018. The US Army in Multi-Domain Operations 2028. https://api.army.mil/e2/c/downloads/2021/02/26/b45372c1/20181206-tp525-3-1-the-us -army-in-mdo-2028-final.pdf

UK Ministry of Defence 2020. Introducing the Integrated Operating Concept. https://www.scribd.com/document/478235470/UK-Introducing-the-Integrated -Operating-Concept-2025\#from_embed

UK Ministry of Defence 2021. Red Teaming Handbook. https://assets.publishing.service.gov.uk/government/uploads/system/uploads/attachment _data/file/1027158/20210625-Red_Teaming_Handbook.pdf

Warfare Development Talks on Multi-Domain Operations Approach 2021. június 16-17. ACT/SPP/WDF/TT- 4160/SER:NU0541 